\title{
Correction to: Animal Cell Expression Systems
}

\author{
M. Butler and U. Reichl
}

\section{Correction to:}

Chapter "Animal Cell Expression Systems" in: M. Butler and U. Reichl, Adv Biochem Eng Biotechnol, DOI: 10.1007/10_2017_31

On page 3, as per the author's request the current list of abbreviations is replaced with complete list of abbreviations.

\section{Abbreviations}

$\begin{array}{ll}\text { ADCC } & \text { Antibody-dependent cellular cytotoxicity } \\ \text { AGE1.CR } & \text { Muscovy duck cell line } \\ \text { AIDS } & \text { Acquired immune deficiency syndrome } \\ \text { B-cell } & \text { White blood cell of the lymphocyte subtype } \\ \text { CAP cells } & \text { Primary human amniocyte-derived cell line } \\ \text { Cas } & \text { Castanospermine } \\ \text { CD4 }{ }^{+} \text {T } & \text { T helper cell type } \\ \text { CGE } & \text { Capillary gel electrophoresis } \\ \text { cGMP } & \text { Current good manufacturing practice } \\ \text { CHO cells } & \text { Chinese hamster ovary cell line } \\ \text { CMP } & \text { Cytidine monophosphate } \\ \text { CQA } & \text { Crucial quality attribute } \\ \text { DO } & \text { Dissolved oxygen } \\ \text { DOE } & \text { Design-of-experiment }\end{array}$

The updated online version of this chapter can be found at DOI 10.1007/10_2017_31 


\begin{tabular}{|c|c|}
\hline EB66 cells & Cell line derived from duck embryonic stem cells \\
\hline EMA & European Medicines Agency \\
\hline ER & Endoplasmic reticulum \\
\hline F243A & Replacement of phenylalanine 243 by alanine \\
\hline $\mathrm{Fc}$ & Fragment crystallizable region \\
\hline FDA & Food and Drug Administration \\
\hline flublok $^{\circledR}$ & Recombinant insect cell-derived influenza vaccine \\
\hline G2 & Digalactosylated oligosaccharide \\
\hline Gal & Galactose \\
\hline GalT & Galactosyl transferase \\
\hline GDP & Guanosine diphosphate \\
\hline GI & Galactosylation index \\
\hline Glc & Glucose \\
\hline GlcNAc & $\mathrm{N}$-acetylglucosamine \\
\hline Gln & Glutamine \\
\hline GlycoVis & Software to describe glycosylation pathways \\
\hline GT & Glycotransferase \\
\hline HA & Hemagglutinin \\
\hline HA0 & Uncleaved form of the HA protein \\
\hline HA1 & Hemagglutinin subunit \\
\hline HA2 & Hemagglutinin subunit \\
\hline HEK293 & Human embryonic kidney cells \\
\hline HexNAc & $\mathrm{N}$-acetyl hexosamine \\
\hline HILIC & Hydrophilic interaction liquid chromatography \\
\hline HIV & Human immunodeficiency virus \\
\hline $\operatorname{IgG}$ & Immunoglobulin $\mathrm{G}$ \\
\hline IVA & Influenza A virus \\
\hline Kif & Kifunensine \\
\hline LIF & Laser-induced fluorescence \\
\hline Mab & Monoclonal antibody \\
\hline MALDI & Matrix assisted laser desorption ionization \\
\hline Man & Mannose \\
\hline ManNAc & $\mathrm{N}$-acetylmannosamine \\
\hline MRC-5 cells & Diploid human fibroblast cells derived from lung tissue \\
\hline MDCK cells & Madin Darby canine kidney cell line \\
\hline MMR & Measles-mumps-rubella \\
\hline MS & Mass spectrometry \\
\hline MTU $^{\prime}$ & Migration time units \\
\hline NA & Neuraminidase \\
\hline NANA & $N$-acetylneuraminic acid \\
\hline NGNA & $\mathrm{N}$-glycolylneuraminic acid \\
\hline NS0 & Non-immunoglobulin-secreting murine myeloma cells \\
\hline PAT & Process analytical technology \\
\hline PER.C6 & Human cell line \\
\hline PNGase $\mathrm{F}$ & Peptide- $N$-glycosidase-F \\
\hline
\end{tabular}




$\begin{array}{ll}\text { PR8/34 } & \text { Puerto Rico/8/34 } \\ \text { QbD } & \text { Quality by design } \\ \text { Qp } & \text { High specific productivity } \\ \text { RFU } & \text { Relative fluorescence units } \\ \text { RPH } & \text { Relative peak height } \\ \text { Sabin } & \text { Live attenuated oral polio vaccine } \\ \text { SARS } & \text { Severe acute respiratory syndrome } \\ \text { Salk } & \text { Inactivated polio vaccine } \\ \text { SF } & \text { Serum-free insect cell line } \\ \text { STR } & \text { Stirred tank reactor } \\ \text { Swa } & \text { Swainsonine } \\ \text { TOF } & \text { Time of flight } \\ \text { TPH } & \text { Total peak height } \\ \text { UDP } & \text { Uridine diphosphate } \\ \text { UMG } & \text { Uridine, manganese and galactose } \\ \text { Vero cells } & \text { African green monkey kidney cell line } \\ \text { WHO } & \text { World Health Organization }\end{array}$

